\title{
Indigenous Grasses for Rehabilitating Degraded African Drylands
}

\section{Mganga, K.Z}

Springer

2019-05-23

Mganga , K Z , Nyariki , DM , Musimba , NKR \& Mwang'ombe , AW 2019 , Indigenous Grasses for Rehabilitating Degraded African Drylands . in Y Bamutaze , S Kyamanywa , B R Singh , G Nabanoga \& R Lal (eds), Agriculture and Ecosystem Resilience in Sub Saharan Africa : Livelihood Pathways Under Changing Climate . Climate Change Management, Springer , Springer, Cham , pp. 53-68 .https://doi.org/10.1007/978-3-030-12974-3_3

http://hdl.handle.net/10138/330181

https://doi.org/10.1007/978-3-030-12974-3_3

unspecified

acceptedVersion

Downloaded from Helda, University of Helsinki institutional repository.

This is an electronic reprint of the original article.

This reprint may differ from the original in pagination and typographic detail.

Please cite the original version. 


\title{
Indigenous grasses for rehabilitating degraded African drylands
}

Kevin Z. Mganga ${ }^{1}$, Dickson M. Nyariki ${ }^{2,3}$, Nashon K.R. Musimba ${ }^{1}$, Agnes W. Mwang'ombe ${ }^{4}$

\author{
${ }^{1}$ Department of Range and Wildlife Sciences, South Eastern Kenya University \\ ${ }^{2}$ Department of Agricultural and Agribusiness, South Eastern Kenya University \\ ${ }^{3}$ School of Business and Economics, Murangá University of Technology \\ ${ }^{4}$ Department of Plant Science and Crop Protection, University of Nairobi
}

\begin{abstract}
Drylands provide an important livelihood stream to its inhabitants across the globe through a range of products and ecosystem services. However, these fragile ecosystems are threatened and believed to experience various degrees of land degradation. Estimates of the landmass affected by land degradation in the global drylands range from 10 to $20 \%$, a percentage that is increasing at an annual global rate of 12 million ha of soil lost from desertification and drought. African drylands are especially highly susceptible to severe degradation because of their poor soil structure aggravated by scarce vegetation cover. Causes of degradation in these environments are both natural and anthropogenic in nature. Change in vegetation cover, decline in soil fertility, biodiversity loss and soil erosion demonstrate degradation in African drylands. Grass reseeding using indigenous species is one of the promising sustainable land management strategy to combat degradation in the drylands. Reseeding programmes are aimed at improving vegetation cover, biomass and conserve the soil to an extent not possible by grazing and land management alone. Indigenous drought tolerant grasses notably African foxtail grass (Cenchrus ciliaris), Bush rye grass (Enteropogon macrostachyus) and Maasai love grass (Eragrostis superba) have produced promising rehabilitation outcomes. Previous studies in African drylands have demonstrated the potential of such indigenous forage grasses in improving both vegetation cover (plant frequency and densities, basal cover) and soil hydrological properties (increased infiltration capacity, reduced runoff and sediment production) as indicators of rehabilitation success. Despite their comparative and widespread success, natural and anthropogenic challenges persist. This makes reseeding programmes a risky and often expensive venture especially for the resource poor pastoral communities in African drylands. Despite the risks, grass reseeding using indigenous pastures remains a viable sustainable land management option to combat degradation in African drylands. However, to ensure its continued success in the long-term, multifaceted approaches and strategies that will integrate land and water management and seed systems suitable for African drylands need to be developed, strengthened and promoted.
\end{abstract}

Key words: Degradation, Reseeding, Desertification, Vegetation cover, Infiltration Capacity, Runoff 


\subsection{Introduction}

Land degradation is a major environmental problem of global significance. It is described as the persistent reduction in the bundle of goods and services provided to human by the ecosystem under consideration (Verstraete et al. 2009). Degradation can also be defined as the loss of both biological and economic productivity, which includes deterioration of soil, vegetation and water. These processes are attributed to climatic variations, human activities, or a combination of both factors (Mganga et al. 2018). Land degradation occurs in the forms of impoverishment and depletion of vegetative cover, loss of biophysical and economic productivity through exposure of the soil surface to wind and water erosion, salinisation and water logging leading to deterioration of physical, chemical and biological soil properties.

Global drylands, comprising hyper-arid, arid, and semi-arid lands with very low $(<0.65)$ ratio of longterm mean annual precipitation to potential evapotranspiration ratios are considered the most threatened by land degradation. These xeric environments are estimated to occupy approximately $38 \%$ of the earth's surface (Verstraete et al. 2009). In these areas land degradation of which desert encroachment is only a small part, is widespread and thus very important. Additionally, wetland enclosures in drylands are affected by desertification through deforestation and subsequent erosion of soils and loss of nutrients. Semi-arid to weakly arid lands of Africa are particularly vulnerable as they have fragile soils, localised high population densities and generally a low input form of agriculture (Mganga et al. 2015). Africa is particularly threatened because land degradation affects about $73 \%$ of the continent (Mganga et al. 2018; Gisladottir and Stocking, 2005). For example, in Kenya, it has been estimated that approximately $30-40 \%$ of the arid and semi-arid lands (ASALs) are quickly degrading and that another $2 \%$ has completely been lost through this process. High rates of soil loss up to 50 tonnes per hectare annually from degraded grazing lands in semi-arid areas are common (Nyangito et al., 2009). According to Nyangito et al. (2009) grazing contributes about $34.5 \%$ of the total soil degradation.

Although some land degradation is attributable to natural causes (climate change, droughts, and localised weather events), a substantial part can be attributed to human activities. Drylands are characterised by limited availability of arable land, limited and highly variable rainfall and scarcity of water resources. Demands placed on land and water resources by rapidly expanding populations, through agricultural intensification, urbanisation and industrialisation have combined to intensively exploit these natural resources. Moreover, resource use strategies are largely exploitative leading to land degradation. The principal causes of degradation in the African drylands can generally be grouped into two (2) categories namely:

1. Removal of vegetation through: cutting and uprooting trees and shrubs, ploughing previously uncultivated and marginal land for annual cropping and overgrazing natural rangelands. 
2. Agricultural intensification using inappropriate cultural practices that degrade soil fertility and encourage erosion, and overuse of irrigation that leads to poor drainage, water logging, rising water-tables and salinisation.

Overgrazing and deforestation removes the vital soil cover, exposing the soil to erosion. Overcultivation which refers to the cropping of the land without replenishing the plant nutrients exhausts the soil, destroying its structure and fertility. Reduction of land productive potential through degradation is not only linked to destructive human activities, but also associated with human-induced global warming and climate change on a global scale. The destruction of forests that are important carbon sinks contribute to higher carbon-dioxide $\left(\mathrm{CO}_{2}\right)$ concentration in the atmosphere thus global warming.

Grass reseeding has been used successfully as a means of rehabilitating degraded drylands in East Africa (Mganga et al. 2010; 2015; Opiyo et al. 2011; Nyangito et al. 2009), thus reversing the degradation process. Indigenous grass species are more successful in reseeding degraded drylands. As a rule of thumb, the best grasses for a reseeding program are those that are native and found on ecological sites similar to those to be reseeded. This chapter discusses the potential of three important indigenous forage grasses in African drylands namely: African foxtail grass (Cenchrus ciliaris), Enteropogon macrostachyus (Bush rye grass) and Maasai love grass (Eragrostis superba) for rehabilitating arid and semi-arid rangelands and improving soil hydrological properties thus combat desertification and reduce soil erosion, respectively.

\subsection{Reseeding - Common indigenous grasses for reseeding}

\subsection{Reseeding}

The primary purpose of dryland reseeding programs is to improve existing ground cover and biomass to an extent or manner not possible by grazing management alone. This can be accomplished by oversowing into existing vegetation with a superior species, establishing a completely new pasture, with or without the aid of irrigation and reseeding a denuded land. Grass reseeding programs are not new in the ASALs of Kenya. In the pre and post-colonial eras of the 1950's and 1960's respectively, a number of reseeding techniques were developed and introduced in Machakos, Taita-Taveta, Baringo and Kitui and Kajiado counties. These reseeding programs were aimed at rehabilitating degraded drylands for improved pasture and livestock production. It is worth noting that reseeding programs can sometimes be costly and risky, especially in arid and semiarid ecosystems. In many ASALs, the cost of rehabilitating a degraded pastureland may by far exceed the potential returns from livestock production. Furthermore, rehabilitation techniques are often unreliable in environments where precipitation is unpredictable, especially in dryland climates characterised by large spatial and temporal variations in 
rainfall. Moisture conditions suitable for active growth are usually short- lived and unpredictable in many instances.

Traditional methods of reseeding degraded ASALs are expensive and often unsuccessful, due to the high rates of seed and seedling mortality and predation. As a rule of thumb, seeding should not be attempted in areas with less than $300 \mathrm{~mm}$ of average annual rainfall because they are apt to fail. When a seed stock is healthy, only two environmental factors will stop it from germinating and establishing in the semi-arid drylands, namely soil type and moisture. Apart from soils and rainfall, other factors including human interventions (burning and grazing) and individual species physiological and morphological differences affect germination and subsequent growth. Successful reseeding has however been achieved in low rainfall areas e.g. Thar Desert in India where the rainfall ranges between $100-500 \mathrm{~mm}$ annually, $90 \%$ of which is received between July and September (Chauhan 2003). This is only achievable with water management. Water harvesting techniques such as pitting, contour furrows and trenches are important for the creation of both micro-catchments and macro-catchments. In semiarid drylands in Kenya, carve half-moon shaped micro-catchments in checkerboard fashion are constructed along slopes of land, situated in such a way as to capture and retain rainwater. Half-moons are used to rehabilitate degraded land for crop cultivation and fodder production, conserve water and fertile soil, improve soil fertility, with the addition of compost, expand agricultural land and improve the infiltration and stock of water in the soil. Such techniques are used in reducing run-off, thus ensuring that the grass seeds get enough water for a prolonged period of time thus improving their chances of germination and subsequent establishment.

Drylands reseeding require soil disturbance. Minimal soil disturbance helps in replenishing deficient plant species by allowing seedling root penetration through provision of conditions suitable for germination, emergence and subsequent establishment (Mganga et al. 2015). Different methods are used to prepare denuded lands for reseeding. These methods include seed bed preparation and soil disturbance and involve some form of rain water harvesting through creation of micro-catchments. This ensures that all available moisture is utilised effectively to increase water penetration and slow run-off. Low cost techniques for the rehabilitation of drylands are more sustainable. Soil disturbance by the use of an ox-drawn plough and hand hoes to create micro-catchments to trap enough moisture for seed germination are among the most economical practices for resource poor farmers in the drylands. Field preparation methods and techniques are defined by such factors as the size of area to be reclaimed, degree of degradation, soil types, rainfall, amount and type of invasive species, presence of wildlife, and the financial and human resources available. 


\subsection{Indigenous grasses for reseeding}

Over the years, indigenous grasses in African drylands have evolved adaptive mechanisms for survival in harsh arid and semi-arid environments. This has made them the preferred choice in many dryland reseeding programmes in Africa (Opiyo et al. 2011; Mganga et al. 2010). They are widespread in Africa and occur mostly in savannas and woodland vegetation types (Fig. 1). Furthermore, perennial grasses are preferable to all other plants, except in eco-climate zone VI, where rainfall is mostly too low to support perennials and where annual grasses are favoured. Perennial grasses have the ability to survive dry seasons and regenerate with each rain to produce fresh growth from the original rootstock. Moreover, perennial grasses have good self-seeding ability. Thus, with proper management, they can establish and spread quickly to give good cover. Although perennials may produce seed every season, they leave for a few to several years.

Generally, grasses selected for reseeding programmes in African drylands should be drought tolerant to survive and perpetuate itself, provide a good quantity of herbage of fair or good grazing value, produce adequate amount of viable seed, which can be easily harvested, and easy to establish (Opiyo et al. 2011; Mganga et al. 2010; 2015). In addition to these characteristics, tolerance to grazing and ability to establish fast during spells of favourable climatic conditions are very important traits in choosing grass species for reseeding (Jordan 1957). Previous reseeding programmes in arid and semi-arid environments in Kenya (Nyangito et al. 2009; Mganga et al. 2010; 2015; Opiyo et al. 2011) have demonstrated rehabilitation success using African foxtail grass (Cenchrus ciliaris), Horsetail grass (Chloris roxburghiana), Star grass (Cynodon dactylon), Bush rye grass (Enteropogon macrostachyus) and Maasai love grass (Eragrostis superba).

\subsubsection{African foxtail grass (Cenchrus ciliaris $\mathrm{L}$ )}

Cenchrus ciliaris (photo plate 1) is native to tropical and sub-tropical Africa and one of the most drought-tolerant of perennial grasses. It is an extremely variable species, tufted (sometimes shortly rhizomatous) and persistent perennial which occurs in a wide variety of types, some of which have become reputed cultivars (Marshall et al. 2012). Numerous cultivars have been created in order to improve productivity and vigour in extreme conditions of drought, disease and frequent fires. The panicle is erect or nodding with a bur-like fascicle comprising a single spikelet or cluster spikelets, surrounded by an involucre of bristles of various lengths. Bristles are barbed and hairy, giving the fascicle an adhesive quality thus dispersed profusely by clinging to animal fur and by wind as well (Marshall et al. 2012). Cenchrus ciliaris free-seeding nature can make it a major pasture component by simply spreading into relatively undisturbed native pasture from nucleus areas established by traditional methods. Cenchrus ciliaris has a deep strong fibrous root system that exceeds $2 \mathrm{~m}$. It is a particularly 
aggressive grass, by virtue of its extensive root system competing with associated species for water and nutrients. It also appears to be allelopathic (Mganga et al. 2015).

It occurs in the wild on sandy soils, but is also well adapted to deep, freely draining sandy loams, loams, clay loams and red earth soils. Cenchrus ciliaris has been recommended for reseeding areas receiving an annual rainfall of $350-900 \mathrm{~mm}$. Whole seeds of this grass species have been shown to result in better grass stands than when hulled seeds are used (Opiyo et al. 2011). Seeds of $C$. ciliaris germinate better after pre-drying for 10 days at $40^{\circ} \mathrm{C}$ than pre-chilling for the same period at $5^{\circ} \mathrm{C}$ (Hussey and Bashaw 1996). Degraded pastures in the drylands are reseeded with $C$. ciliaris to enhance productivity, prolong grazing period and increase carrying capacity. Furthermore, it is a palatable and nutritious grass species, highly nutritious forage for livestock and recovers well from grazing (Marshall et al. 2012). It produces reasonable quality hay when cut in the early flowering stage, yielding up to $2500 \mathrm{~kg} / \mathrm{ha}$ per cut with a protein content of 6-10\% of dry matter (Koech et al. 2016).

\subsubsection{Bush rye grass (Enteropogon macrostachyus A. Rich. Munro ex Benth.)}

Enteropogon macrostachyus (photo plate 2) is native species to Africa. It is a widely distributed perennial grass species very common in arid and semi-arid areas where it grows in bush, forest edges and to a lesser extent in open grassland (Opiyo et al. 2011). It is a tufted perennial suitable for reseeding rock slopes or bushland. It has proved an excellent grass for reseeding African drylands under moderately dry conditions. This species has been tried with moderate success for reseeding denuded pastoral land in Kenya (Mganga et al. 2015) under annual rainfall of 550-800mm. Enteropogon macrostachyus is a good grass for arid and semi-arid ecosystems because it is drought resistant.

This species has erected culms of 30-100cm high. Leaf sheaths are without a keel. Surface of the sheath and outer margins are glabrous. Leaf blades are narrow and flat, approximately $10-60 \mathrm{~cm}$ long and 1.5$10 \mathrm{~mm}$ wide. Depending on the environmental conditions E. macrostachyus may be leafy or stemmy. Although stemmy, it is drought resistant and provides useful grazing for grazing herbivores. Previous studies (e.g. Koech et al. 2016), have shown E. macrostachyus to have a crude protein and crude fibre percentages of $5.2 \%$ and $28 \%$ respectively.

In tropical Africa, E. macrostachyus occurs naturally in open rangelands and rocky outcrops in semiarid environments at an altitude ranging between 300-1600m above sea level. The species occurs in areas receiving around $600 \mathrm{~mm}$ of rainfall per annum. It is a very good seeder and seed can be collected rapidly by cutting the seed-heads or stripping the heads by hand. It lends itself easily to mechanical harvesting. The seeds germinate readily and grow vigorously. It is palatable thus its re-introduction in degenerated swards is of obvious value to grazers (Opiyo et al. 2011). 


\subsubsection{Maasai love grass (Eragrostis superba Peyr.)}

The grass species derives its scientific name from both Greek and Latin words. Eragrostis comes from the Greek words Eros meaning love and this possibly refers to the heart shaped spikelets; and Agrostis meaning grass. The species name superba is the Latin for splendid, probably descriptive of the spikelets. Eragrostis superba (photo plate 3) occurs naturally in South Africa and northwards throughout East Africa to Sudan. It is wide spread in the semi-arid areas of East Africa and is very common in various vegetation types mainly grassland and savannah types, rocky and sandy areas throughout its ecological range.

Eragrostis superba is a tufted perennial 20-120cm high with a high shoot/root ratio (Opiyo et al. 2011) which is a disadvantage during drought periods but is advantaged by having deep root system which go as far as $2.2 \mathrm{~m}$ with $73 \%$ of the roots limited to the upper $0.4 \mathrm{~m}$ from the soil surface, which enable the grass to make full use of light showers of rain (Opiyo et al. 2011; Mganga et al. 2010; 2015). It is a moderate tiller with a poor regrowth ability compared to C. ciliaris and C. roxburghiana. Eragrostis superba grows in disturbed places and thus has been used successfully for reseeding denuded and pastoral drylands and soil erosion control in dryland Africa (Nyangito et al. 2009; Mganga et al. 2010; 2015; Opiyo et al. 2011) because of it has excellent establishment characteristics. It has been successful in the semi-arid areas of East Africa particularly in eco-climatic zone VI where mean annual rainfall ranges between 500-900mm. Eragrostis superba occurs at an altitude of 0-2000m above sea level. Eragrostis superba, along with $C$. ciliaris have been the basis of the seed mixtures used for large-scale reseeding programmes in ASALs in Kenya.

Eragrostis superba is a quick growing species and shows green vegetative growth almost throughout the year and has good drought tolerance. It is very palatable when young. Depending on the soil types and other environmental conditions, chemical and digestibility analyses indicate that the grass has between $5-12 \%$ crude protein $(\% \mathrm{CP})$ in the dry matter at an early-flowering stage with $25-35 \%$ crude fibre (\%CF) (Koech et al. 2016). Wasonga et al. (2003) demonstrated that pastoral communities in Kenya have identified E. superba as one of the grass species suitable for fattening and improving the condition of their livestock herd. The grass species grows very easily from seeds which are in the form of a small, plump grain, which are particularly susceptible to insect damage. The grass seeds can be collected easily from open grassland or at roadsides by stripping the ripe panicles. Mature spikelets, each with numerous florets, detach easily with the caryopses enclosed. The grass can be established in gravely, sandy, loamy or clay soils. However, it does best in sandy soils but occurs also on clay loams and clays. The species has a high tolerance to salinity and alkalinity and can also be found on termite mounds common in the African drylands. 


\subsection{Ecological indicators I - Vegetation characteristics}

Vegetation attributes e.g. biomass yields, plant frequency, plant density, basal cover and seed production have been used in past ecological study to assess the success of reseeding programmes in dryland environments. Table 1 below highlights some of the vegetation attributes of indigenous grass species used for rehabilitating degraded dryland environments in Africa.

Table 1: Vegetation attributes of some indigenous grass species used for reseeding programmes

\begin{tabular}{llllll}
\hline Grass species & $\begin{array}{l}\text { Biomass } \\
\text { yield } \\
(\mathrm{kg} / \mathrm{ha})\end{array}$ & $\begin{array}{l}\text { Plant } \\
\text { frequency } \\
(\%)\end{array}$ & $\begin{array}{l}\text { Plant density } \\
\left(\text { plants } \mathrm{m}^{-2}\right)\end{array}$ & $\begin{array}{l}\text { Basal cover } \\
(\%)\end{array}$ & $\begin{array}{l}\text { Seed } \\
\text { production } \\
(\mathrm{kg} / \mathrm{ha})\end{array}$ \\
\hline C. ciliaris & $1026.6 \pm 55 \mathrm{a}$ & $44.4 \pm 19.63 \mathrm{a}$ & $7 \pm 5.23 \mathrm{a}$ & $30 \pm 26.44 \mathrm{a}$ & $145 \pm 13 \mathrm{a}$ \\
\hline E. macrostachyus & $744.0 \pm 28 \mathrm{~b}$ & $72.3 \pm 25.43 \mathrm{~b}$ & $36 \pm 2.1 \mathrm{~b}$ & $54 \pm 19.29 \mathrm{~b}$ & $56 \pm 25 \mathrm{~b}$ \\
\hline E. superba & $896.5 \pm 44 \mathrm{c}$ & $38.7 \pm 9.82 \mathrm{a}$ & $5 \pm 6.25 \mathrm{a}$ & $23 \pm 15.44 \mathrm{a}$ & $119 \pm 17 \mathrm{c}$
\end{tabular}

Column means followed by different letters are significantly different at $\mathrm{P}<0.05$

Source: Modified from Mganga et al. (2010)

Differences plant frequency, plant densities and basal cover among the grass species is explained by germination success and seedling emergence rates and subsequent establishment of the seedlings. Nature, morphology and size of the seeds determine germination percentage, thus percentage frequency, plant density and basal cover (Mganga et al. 2010; 2015). Seed size has an effect on seedling emergence. Vegetation attributes highlighted in Table 1 above clearly demonstrates that E. macrostachyus has the best rehabilitation results among the three species. Higher frequency of E. macrostachyus is attributed to its bigger seed size compared to C. ciliaris and E. superba. Additionally, E. macrostachyus dormancy mechanism involves only the integument and thus explains its rapid germination relative to the other two grass species. Seed morphology of $C$. ciliaris, characterised by the hairy bristle coat aides germination by maintaining a high humidity within the fascicle and thereby helps reduce water loss from the caryopsis thus enhancing germination (Sharif-Zadeh and Murdoch 2001) as compared to those of E. superba. In addition, these fascicles are known to contain more than one caryopsis (Daehler and Georgen 2005).

\subsection{Ecological indicators II - Soil hydrological properties}

Soil hydrological measurements e.g. infiltration capacity and run-off have been used in previous ecological studies (Nyangito et al. 2009; Mganga et al. 2010) to determine the effect of increased vegetation cover as an indicator of rehabilitation success, in reducing soil erosion. Tables 2 and 3 below 
shows the effect stubble heights of different indigenous grass species used to rehabilitate degraded drylands on soil water infiltration capacity and runoff.

Table 2: Infiltration capacity $(\mathrm{cm})$ in relation to grass stubble heights $(\mathrm{cm})$

\begin{tabular}{llll}
\hline Stubble height $(\mathrm{cm})$ & \multicolumn{3}{c}{ Infiltration capacity $(\mathrm{cm})$} \\
\cline { 2 - 4 } & Cenchrus ciliaris & Enteropogon macrostachyus & Eragrostis superba \\
\hline 0 & $2.07 \mathrm{a}$ & $2.07 \mathrm{a}$ & $2.07 \mathrm{a}$ \\
\hline 20 & $3.02 \mathrm{~b}$ & $2.79 \mathrm{c}$ & $2.11 \mathrm{~d}$ \\
\hline 40 & $3.72 \mathrm{c}$ & $3.48 \mathrm{~d}$ & $2.99 \mathrm{~b}$ \\
\hline
\end{tabular}

Column and row means followed by different letters are significantly different at $\mathrm{P}<0.05$

Source: Modified from Mganga et al. (2010)

All the grass species show a general increase in the infiltration capacity with an increase in stubble height. $C$. ciliaris maintained the highest infiltration capacity of $3.02 \mathrm{~cm}$ and $3.72 \mathrm{~cm}$ at stubble heights of $20 \mathrm{~cm}$ and $40 \mathrm{~cm}$ respectively, compared to the other grasses. Enteropogon macrostachyus had $2.79 \mathrm{~cm}$ and $3.48 \mathrm{~cm}$, and Eragrostis superba recorded $2.11 \mathrm{~cm}$ and $2.99 \mathrm{~cm}$ within the same stubble height range and were ranked second and third respectively.

Table 3: Runoff $(\mathrm{cm})$ in relation to grass stubble heights $(\mathrm{cm})$

\begin{tabular}{llll}
\hline Stubble height $(\mathrm{cm})$ & \multicolumn{3}{c}{ Runoff $(\mathrm{cm})$} \\
\cline { 2 - 4 } & Cenchrus ciliaris & Enteropogon macrostachyus & Eragrostis superba \\
\hline 0 & $1.88 \mathrm{a}$ & $1.88 \mathrm{a}$ & $1.88 \mathrm{a}$ \\
\hline 20 & $0.93 \mathrm{~b}$ & $1.16 \mathrm{c}$ & $1.84 \mathrm{a}$ \\
\hline 40 & $0.23 \mathrm{c}$ & $0.47 \mathrm{~d}$ & $0.96 \mathrm{~b}$
\end{tabular}

Column and row means followed by different letters are significantly different at $\mathrm{P}<0.05$

Source: Modified from Mganga et al. (2010)

Indigenous grasses with higher and lower infiltration capacities gave lower and higher runoffs respectively. Cenchrus ciliaris yielded the lowest run-off of 0.93 and $0.23 \mathrm{~cm}$ at 20 and $40 \mathrm{~cm}$ grass stubble heights, respectively. Enteropogon macrostachyus yielded 1.16 and $0.47 \mathrm{~cm}$ while E. superba recorded run-offs of 1.84 and $0.96 \mathrm{~cm}$ respectively at the same range of grass stubble heights.

Previous studies have demonstrated that perennial vegetation can increase infiltration (Seobi et al. 2005). In their study in a typical semi-arid environment in Kenya, Nyangito et al. 2009 also observed higher infiltration capacity in rehabilitated sites dominated by E. macrostachyus compared to those dominated by E. superba. Differences in infiltration capacity between the different indigenous grasses 
is attributed to their growth and morphological characteristics. Cenchrus ciliaris is densely leafed with branching culms arranged in a funnel shape. It is also relatively broad leafed. These characteristics presents a greater surface area for collecting water and rain drops that is directed more into its rhizosphere. Enteropogon macrostachyus, though narrow leafed, tends to be leafy than stemmy especially at its base and therefore, closely compares with $C$. ciliaris in trapping and directing rain water. In contrast, E. superba has a higher stem to leaf ratio thus less effective in concentrating rainwater into their rhizosphere.

Consequently, these outcomes strongly suggest a general decline in sediment production, and index of sheet erosion, with an increase in grass stubble height. This is attributed to the reduction of the force of water drops hitting and destabilising the soil surface. Generally, vegetation cover intercepts rainfall kinetic energy and thereby decreases the mobilisation of soil particles. Taller grass stubble heights trap more rainwater drops and funnels it down its crown thus concentrating more water around the rhizosphere compared shorter stubble heights. Larger leaf blades also reduce the force of the water drops directly hitting the ground. This improves infiltration capacity, reduces run-off and thus less sediment production (soil erosion).

\subsection{Challenges of rehabilitating degraded drylands using reseeding}

Rainfall in the African drylands are usually low, erratic and unpredictable in both space and time. High variability in rainfall amounts and distribution are common characteristics of semi-arid lands often leading to soil moisture deficits (Ekaya et al. 2001). Low amounts of rainfall and droughts periods characteristic of the African drylands are the main factors which contribute immensely to rangeland rehabilitation failures. Low amounts of rainfall reflected by the soil moisture deficits hinder seed germination. Often reseeded drylands experience poor establishment. When the seed bank is healthy, the main environmental factors that will stop seeds from germinating and establishing in the drylands are soil type and moisture.

Conversely, during heavy rains, drylands are also very susceptible to flush floods leading to massive soil erosion and consequently destruction of reseeded areas. High intensity rainfall that lasts for a very short period of time often causes flush floods in dryland environments in Africa. Coupled with the soils characterised by high levels of salinity, poor drainage, soil erosion, soil compaction, soil crusting and low soil fertility (Nyangito et al. 2009; Opiyo et al. 2011) exposes the sown grass seeds to agents of erosion notably water and wind. Flood waters often transport the sown grass seeds as it flows along the gradient. Furthermore, heavy storms also destroy the micro-catchments created to trap rainwater for the grass seedlings. Soil crusting common in dry environments in Africa further compounds the problem and hinders grass seedling emergence. This combination of climatic and edaphic factors leads to poor rates of germination and thus poor rates of establishment. 
Livestock keeping is the main source of livelihood among pastoral communities inhabiting the African drylands. Grazing animals are mainly kept under free range/herding system in defined household grazing areas (Nyangito et al. 2009). This form of grazing system also contributes immensely to rehabilitation failures. Free grazing animals often cause destruction to young grass seedlings often by trampling on newly established grass stands hindering their subsequent development to maturity and seed setting. Destruction seedlings before seed setting leads to continual deprivation of the seed bank in the soil which in the long-run leads to bare patches.

Fencing is the only way of excluding domestic and wild herbivores from reseeded areas. However, the use of long-lasting fences e.g. chain-link and barbed wire is often expensive for the pastoral and agropastoral communities. Consequently, they are forced to settle for cheap and locally materials notably branches and poles of Acacia and Commiphora species to keep free roaming herbivores. Such materials only provide a short-term solution, since they are easily destroyed by livestock. Continued exposure of the fence to rainfall further weakens and destroys the fence. Moreover, notorious herders easily remove the fences to allow their animals graze the newly established seedlings and later replace it. To ensure successful establishment, newly established grass stands should be protected from grazing animals for at least two growing seasons. However, this is hardly possible in pastoral areas.

Seed bed preparation and sowing for reseeding programmes in dryland Africa is mainly done prior to the onset of the rainy season. The grass seeds are sown at a shallow depth and covered with minimal amounts of soil. This guarantees that the sown seeds get enough moisture for germination and consequent establishment. Dry planting ensures that the first showers of rain find the sown seeds in the ground. However, this period also coincides with scarcity of food for rodents, birds and insects. Rats, squirrels and other small rodents and insects often feed on the sown seeds. Termites also transport the seeds for long distances and store them in their food stores. Damage by termites is a general concern in African drylands (Mugerwa 2015) as they also destroy vegetation, crops and farm structures. Additionally, Quelea quelea birds common in African drylands often invade the rehabilitation plots in hundreds and feed on the sown grass seeds, especially those of E. superba which is mostly preferred by pastoralists because of its role in improving milk production (Wasonga et al. 2003). These factors contribute to poor rates of initial germination in some patches.

Inadequate supply of good quality and quantities of indigenous grass seeds e.g. E. macrostachyus, E. superba, C. ciliaris and C. roxburghiana in the formal markets limits their accessibility for use in reseeding programmes. Land-users' needs for herbage seeds are rarely met by formal seed production and marketing systems in sub-Saharan Africa. This is partly attributed to degradation of natural vegetation where grasses are steadily being replaced by more woody vegetation type in the rangelands. 
Consequently, there is a shortage of supply of grass seeds commonly harvested in open grazing areas. Proper seed technology is therefore necessary at harvesting, processing and storage, especially where dryland communities are expected to undertake pasture seed multiplication to meet the current shortage.

Poor post-harvest storage methods, skills and facilities to store harvested seeds and use of poor quality seeds also contribute to poor establishment in reseeded drylands. Due to lack of infrastructure and inadequate knowledge and skills of handling grass seeds, pastoralists inhabiting drylands store seeds harvested in the wild in gunny bags and place them in grass thatched granaries which are sometimes not well done or poorly maintained. Quality of indigenous grass seeds is highly variable and poor in tropical Africa as a result of poor harvesting and storage technology. Dry seeds, especially those of rangeland pasture grasses are known to be highly hygroscopic and exposure of dry seeds to moisture has been reported to worsen seed dormancy and often leads to fungal infection (Mganga et al. 2015). However, the ability to withstand moisture conditions during storage varies between species. During heavy storms, traditional granaries allow some rain water to penetrate thus contaminate the stored grass seeds. This leads to spoilage. Additionally, some of the grass seeds used to reseed denuded patches in the dryland are dormant and often not viable. The seeds used can either be too old or fresh and immature yet to break dormancy.

Competition for limited resources in drylands soils between weeds and reseeded grasses especially during the early stages of development can be very severe. Soils in the semi-arid environments in Africa may contain 1.5 million seeds per hectare on a landscape scale (Witkowski and Garner 2000). This far exceeds the recommended sowing rates of indigenous pasture species usually at 30 - 500 viable seeds $/ \mathrm{m}^{2}$. Some of the common weeds found in established reseeded drylands in semi-arid Kenya include Sodom Apple (Solanum incanum), Milkweed (Lactuca capensis), Kitui Morning Glory (Ipomoea kituensis), Crab Grass (Digitaria scalarum), Weeping Lovegrass (Eragrostis curvula), Jimson Weed (Datura stramonium), Coat Buttons (Tridax procumbens), Barleria taitensis, Wandering Jew (Commelina bengalensis) and Natal Grass (Rhynchelytrum repens). Ipomoea kituensis is a very common and notorious weed in reseeded pastures in semi-arid lands in Kenya. It spreads very fast and thus colonises a wide area within a very short period, making it difficult to eradicate. Its creeping nature engulfs newly established grass seedlings suppressing their growth and development by depriving them of sunlight necessary for normal photosynthetic function. Furthermore, due to its aggressive nature, $I$. kituensis often out-competes the grass seedlings for soil nutrients and water.

\subsection{Conclusions}

Land degradation is an environmental problem of great importance in the African drylands. Both human and climatic factors contribute significantly to accelerated degradation in the dryland environments. 
Grass reseeding, using indigenous perennial grasses is a viable option to combat degradation and halt the desertification process in African drylands. Previous studies have shown that reseeded areas improve vegetation attributes such as cover, biodiversity and density. These consequently enhance soil hydrological properties notably increased water infiltration and decreased runoff, thereby significantly reduce soil loss. Despite its widespread success, grass reseeding programmes in Africa continue to face multifaceted challenges that hinder their full potential in rehabilitating degraded drylands. This necessitates multi-stakeholder collaborations and interaction between land users, researchers, local and national governments and other non-governmental organisations and institutions to develop and introduce multifaceted sustainable land management technologies to combat land degradation in dryland environments. Such initiatives in African drylands, a hotspot for successful land restoration projects due to innovations in technology and social engineering, will go a long way to supporting sustainable rural livelihoods and promote environmental management.

\section{References}

Chauhan SS (2003). Desertification control and management of land degradation in the Thar desert of India. Environmentalist 23: 219-227.

Daehler C, Georgen EM (2005). Experimental restoration of an indigenous Hawaiian grassland after invasion of buffel grass (Cenchrus ciliaris). Restoration Ecology 13: 380-389.

Ekaya WN, Kinyamario JI, Karue CN (2001) Abiotic and herbaceous vegetational characteristics of and arid rangeland in Kenya. African Journal of Range and Forage Science 18: 125-129.

Gisladottir G, Stocking M (2005). Land degradation control and its global environmental benefits. Land Degradation and Development 16(2): 99-112.

Hussey AM, Bashaw EC (1996). Performance of buffel grass germplasm with improved winter survival. Agronomy Journal 88:944-946.

Jordan SM (1957). Reclamation and pasture management in the semiarid areas of Kitui district, Kenya. East African Agricultural and Forestry Journal 25: 18-22.

Koech OK, Kinuthia RN, Karuku GN, Mureithi SM, Wanjogu R (2016). Field curing methods and storage duration affect the quality of hay from six rangeland grass species in Kenya. Ecological Processes 5: 3. https://doi.org/10.1186/s13717-016-0048-2

Küchler AW, Zonneveld IS (1988). Handbook of Vegetation Science

Marshall VM, Lewis MM, Ostendorf B (2012). Buffel grass (Cenchrus ciliaris) as an invader and threat to biodiversity in arid environments: a review. Journal of Arid Environments 78: 1-12.

Mganga KZ, Nyariki DM, Musimba NKR, Amwata DA (2018). Determinants and rates of land degradation: Application of stationary time-series model to data from a semi-arid environment in Kenya. Journal of Arid Land 10(1): 1-11. 
Mganga KZ, Musimba NKR, Nyariki DM, Nyangito MM, Mwangombe AW (2015). The choice of grass species to combat desertification in semi-arid Kenyan rangelands is greatly influenced by their forage value for livestock. Grass and Forage Science 70: 161-167.

Mganga KZ, Musimba NKR, Nyangito MM, Nyariki DM, Mwang'ombe AW (2010). Improving hydrological properties of degraded soils in semi-arid Kenya. African Journal of Plant Sciences and Technology 4: 138-144.

Mugerwa S (2015). Magnitude of the termite problem and its potential anthropogenic causes in Nakasongola district of Uganda. Grassland Science 61(2): 75-82.

Nyangito MM, Musimba NKR, Nyariki DM (2009). Hydrological properties of grazed perennial swards in semi-arid southeastern Kenya. African Journal of Environ Science and Technology 3: 26-33.

Opiyo FEO, Ekaya WN, Nyariki DM, Mureithi SM (2011). Seedbed preparation influence on morphometric characteristics of perennial grasses of a semi-arid rangeland in Kenya. African Journal of Plant Science 5: 460-468.

Seobi T, Anderson SH, Udawatta RP, Gantzer CJ (2005). Influence of grass and agroforestry buffer strips on soil hydraulic properties for an Albaqualf. Soil Science Society of America Journal 69:893-901.

Sharif-Zadeh F, Murdoch AJ (2001). The effects of temperature and moisture on after-ripening Cenchrus ciliaris seeds. Journal of Arid Environments 49:823-831.

Verstraete MM, Scholes RJ, Smith MS (2009). Climate and desertification: looking at an old problem through new lenses. Frontiers in Ecology and the Environment 7(8): 421-428.

Wasonga VO, Ngugi RK, Kitalyi A (2003). Traditional range condition and trend assessment: Lessons from Pokot and Il Chamus pastoralists of Kenya. Anthropologist 5(2):79-88.

Witkowski ETF, Garner RD (2000). Spatial distribution of soil seed banks of three African savanna woody species at two contrasting sites. Plant Ecology 149(1): 91-106. 


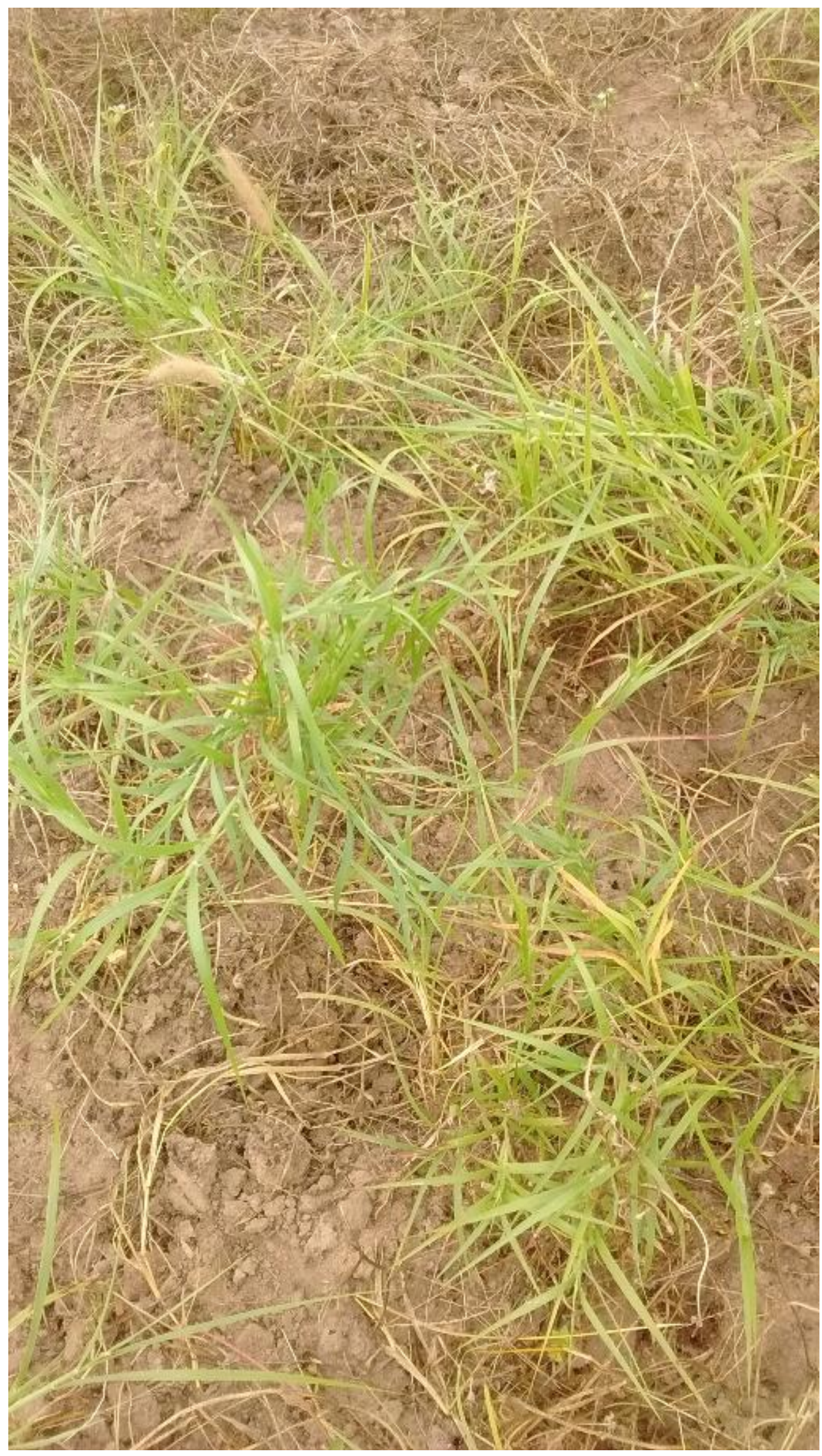

Photo plate 1: African foxtail grass (Cenchrus ciliaris) 


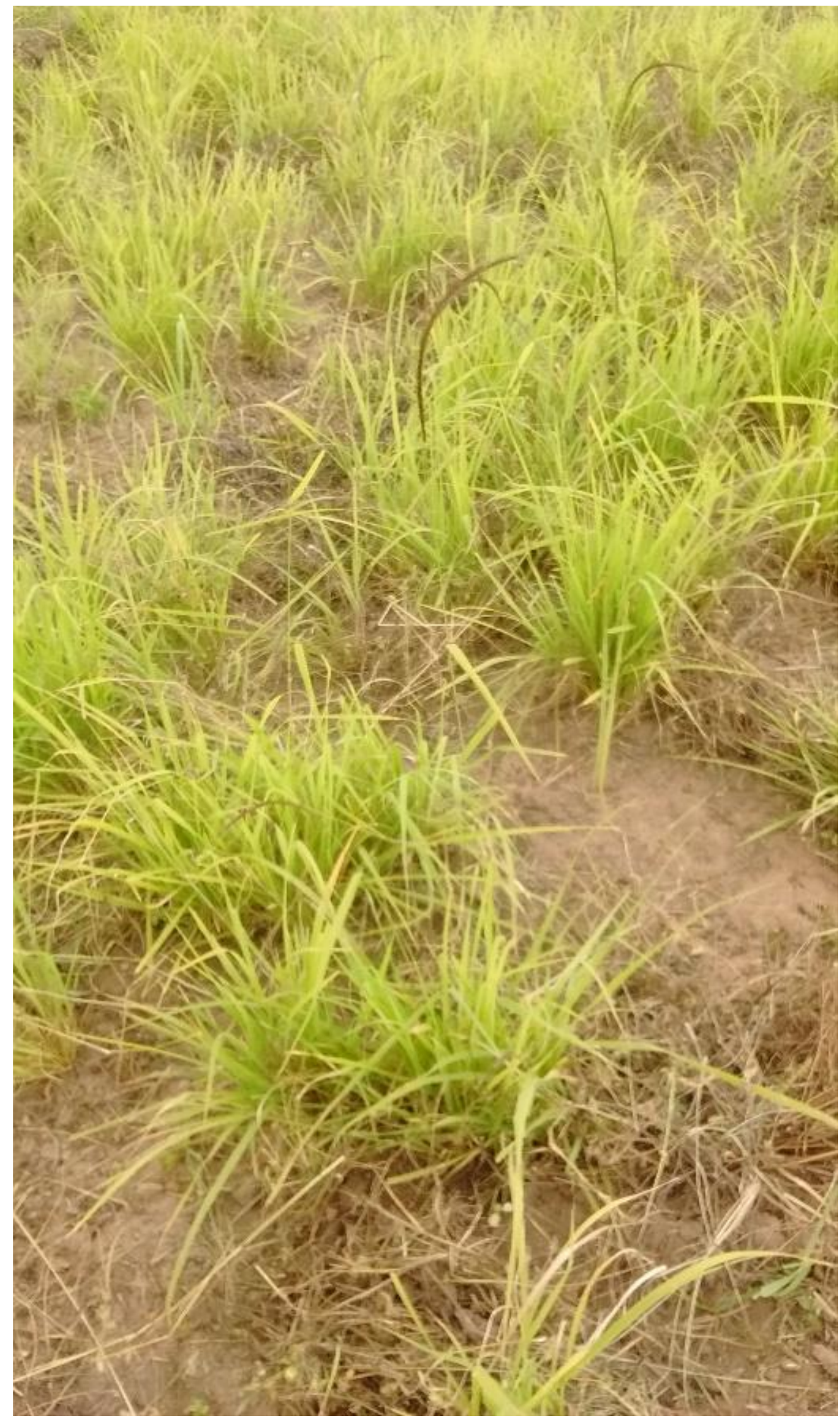

Photo plate 2: Bush rye grass (Enteropogon macrostachyus) 


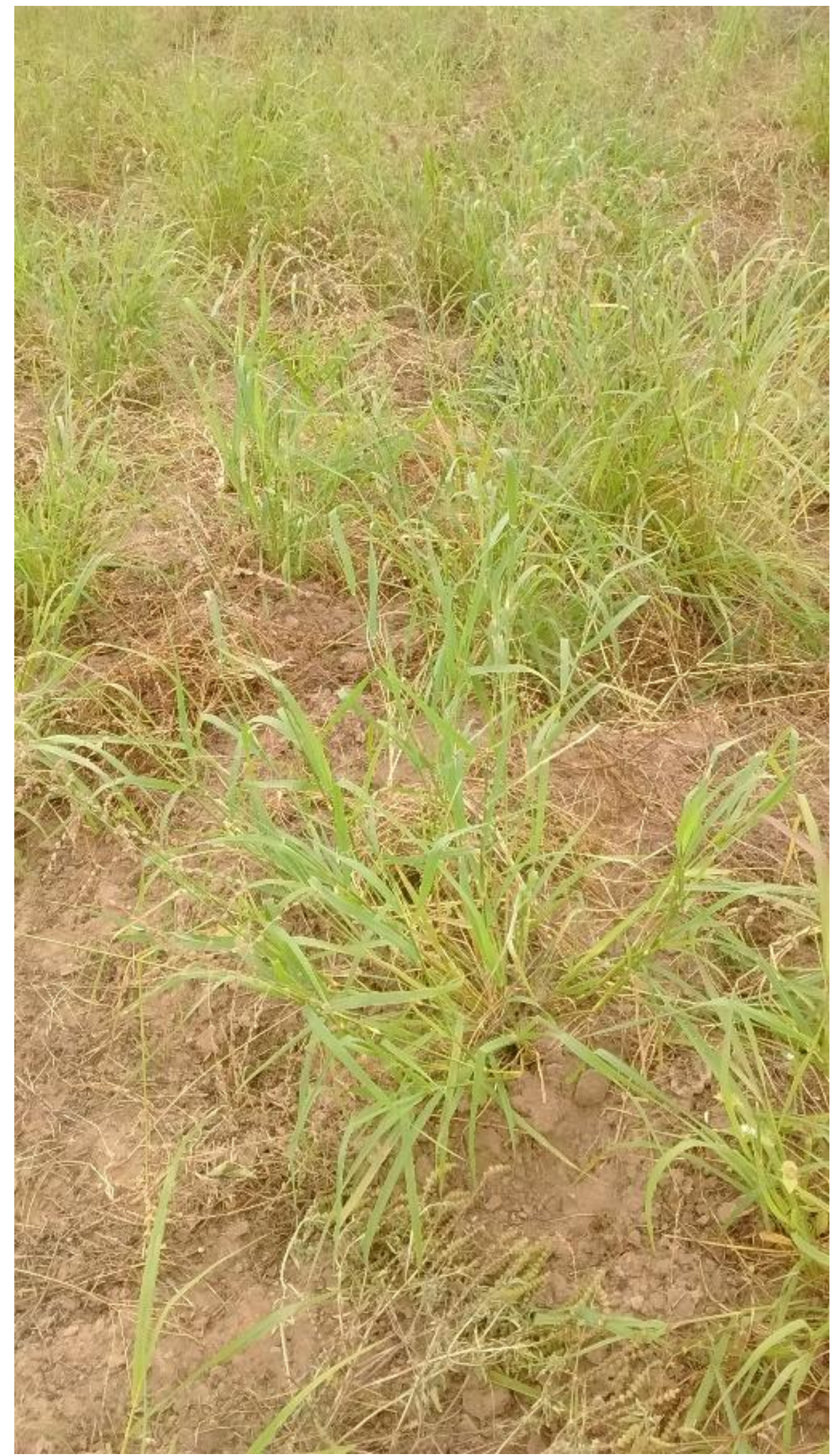

Photo plate 3: Maasai love grass (Eragrostis superba) 


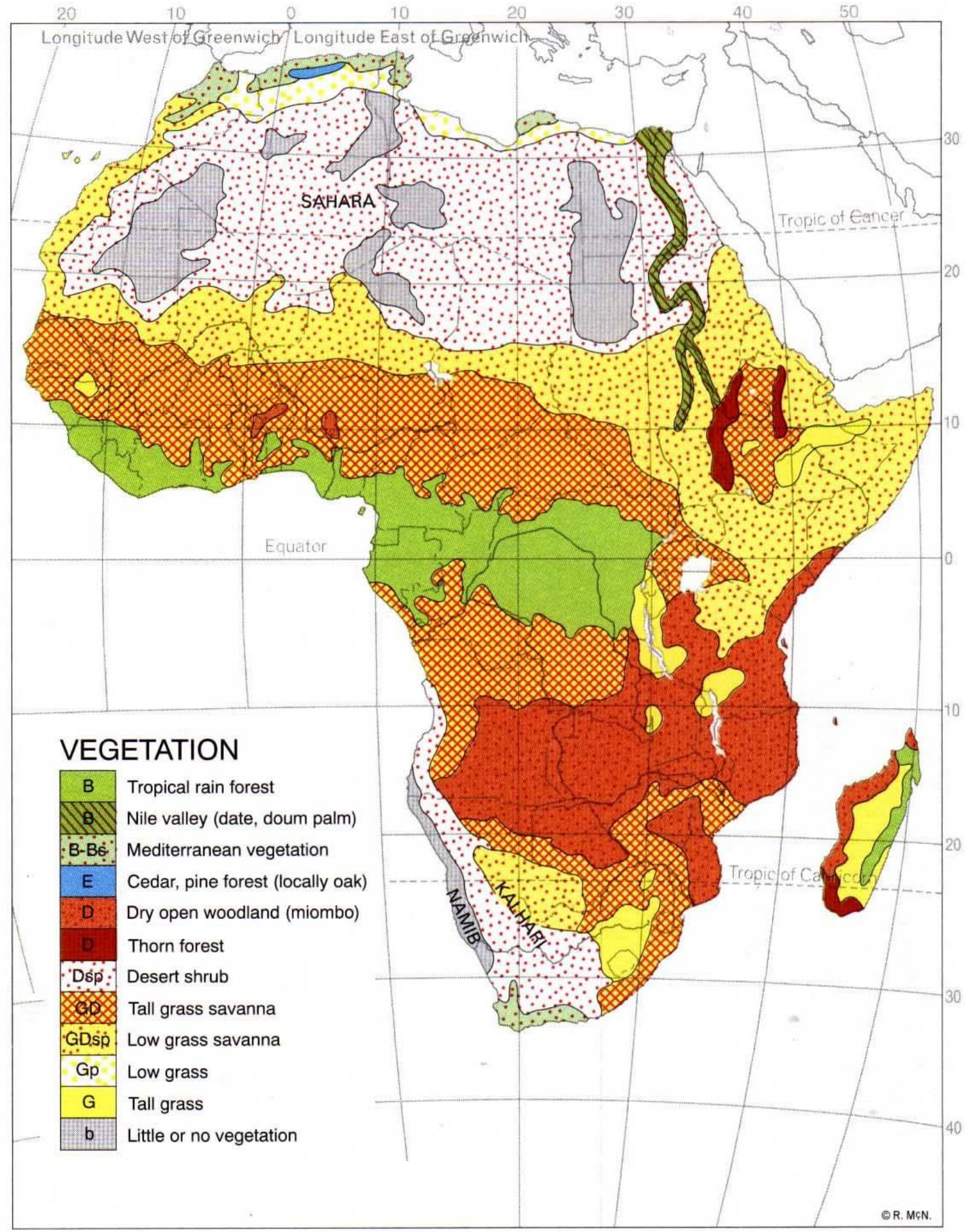

Figure 1: Map of Africa showing different vegetation types. Indigenous grasses occurring primarily in dry open woodland and grassland savannas

Source: Küchler AW and Zonneveld IS (1988) Handbook of Vegetation Science 